\title{
THE INFLUENCE OF POLITICAL STABILITY AND ECONOMIC STABILITY ON THE INFLOW OF FOREIGN CAPITAL IN BOSNIA AND HERZEGOVINA
}

\author{
Ilija Šušić ${ }^{1}$, Milan Šušić ${ }^{2}$, Darija Dragić ${ }^{3}$ \\ ${ }^{1,2}$ University of Business Studies, Banja Luka, Faculty of Business and Financial Studies, Bosnia and \\ Herzegovina \\ ${ }^{3}$ Elektro Krajina, a.d., Banja Luka, Bosnia and Herzegovina \\ i.susic51@gmail.com, m.susic87@gmail.com; darija.dragic@elektrokrajina.com
}

\section{Original Scientific Paper doi:10.5937/jouproman7-22412}

\begin{abstract}
With the Fourth Industrial Revolution (4IR), humanity has entered a new stage of development. The 4IR has become a reality for millions of people around the world, creating new business opportunities, governments and individuals. Nevertheless, it threatens the new political disagreements and contradictions within and between economies and societies. The combination with rising inequalities and geopolitical turmoil has stirred citizens' concerns about globalization and has provoked divided political opinions. Although world economic growth has been stronger over the past two years, the situation in the current changing economic and political context remains fragile.

The World Economic Forum introduced the new Global Competitiveness Index 4.0 (GCI), a highly needed compass, based on a 40-year long experience of analyzing long-term competitiveness drivers.

The results of the global competitiveness index provide impartial information that enables leaders in the public and private sectors to better understand and shape their strategies in the era of the fourth industrial revolution. The paper presents a detailed profile of the economy of Bosnia and Herzegovina as well as tables with global ranking data with all indicators. Using quantitative methods and data from survey surveys, the Competitiveness Report ranks countries based on a combination of 98 indicators grouped in 12 pillars of competitiveness.
\end{abstract}

Key words: competitiveness, research, global ranking, business, economic growth and development, competitiveness pillars.

\section{INTRODUCTION}

In order for a country and / or one region to be attractive to attract foreign investment, it is necessary to create stable business conditions and, if possible, anticipate future economic trends with a high degree of probability, as well as to ensure the existence of lasting social and political stability ${ }^{161}$. Without that, there will be no conditions for dealing with extremely large social problems in most developing countries. Different economic and social situations of individual countries and regions have a disincentive to global political stability and the global stability of the conditions of business, which means that there is no chance for acceleration of economic development until all potentials for the expansion of entrepreneurship are released and of inflow foreign capital.

The democratic political system is a prerequisite for effective economic development. This refers to a political system based on personal freedoms and rights. In this system there should be entrepreneurial initiatives, social justice and peace, market laws, general political stability, regulated position and rights of employees, regulation by the state, institutional protection of foreign investors, as well as the minimum prerequisites for the further existence of the capitalist socio-economic and multipurpose political system. In a democratic country, the drafting and adoption of any public expenditure plan includes many individuals and groups with different objectives and different attitudes regarding the functioning of the economy.

1 Moran, T.H. Foreign Direct Invetment and Development, Peterson Institute for Internnational Economics, Washington, 2011. str. 30-31. 
A plan eventually adopted is a compromise between these attitudes and, in all likelihood, will not fully correspond to the views of any individual, as it may seem to be disconnected from any single objective ${ }^{2}$. However, in democratic countries, expenditure plans and economic efficiency at least partially respond to the wishes and expectations of voters. Programs are often not formulated just as economists think should be formulated, because voters usually do not understand their real reach. Program formulation can affect the extent to which they can be subject to political pressure and corruption.

The prospects for the economic development of a country that is poor, without developed market institutions, without a strong and organized central government that could implement any alternative strategy and development policy, are very gray. Developing countries can hardly achieve macroeconomic stabilization and boost competitiveness of the economy without expansion of production and employment, and an economy based on imports can not support economic growth and development. In order to attract foreign investment, it is necessary to adapt and do a lot of things, because foreign capital goes where it is a politically stable society and where it is safe, or where stable conditions of employment are. Political stability and the stability of the conditions of the economy imposed by globalization must be the imperatives for attracting foreign capital to the country. It has been scientifically proven that economic development is more affected by the stability of the political system than by its type (democracy or dictatorship).

For a political system that is in favor of entrepreneurship, a positive rating is given if it is able to influence the costs of doing business. The argument for setting limits to policy makers is that they can play games with the

2 Stiglitz, J.E. The Economics of Public Sector, McGraw Hill, 2-nd Edition, London, 2003. str. 271. public or between themselves, and such games can lead to undesirable results ${ }^{3}$. Politicians could try to fool the short sighted electorate by choosing policies that benefit in the short term, but high costs in long term (high budget deficits). Political parties can delay important decisions, hoping another political option will take the blame. These problems exist, although they are less superior than they are often thought of. In such cases, firm political constraints can provide a rough solution. A better way involves effective institutions and effective ways of creating a process through which policies and decisions are made.

Often the correctness of economic policies is not the only one that decides on the results of a country's access to key development problems. Political structures and their interests usually determine which strategies are possible and where they can be the main obstacles to productive social and economic changes. The constellation of interest and power among the various segments of the population of most developing countries is itself a result of their economic, social and political history and varies from country to country. Economic and social development is often impossible without proper changes of the country's social, political, legal and economic institutions. The degree to which a country depends on foreign economic, social and political forces is related to its size and wealth of resources. In most developing countries, this dependence is significant. They depend also on foreign investments, on trade with developed countries and on imports of foreign capital-intensive production technologies.

\footnotetext{
${ }^{3}$ Blanchard, O. Macroeconomics, Prentice Hall, New York, 2003. str. 526.
} 
Bosnia and Herzegovina has seriously devoted itself to developing the competitiveness of its companies and investment opportunities, and gives special attention to the factors that influence the development of entrepreneurship. This includes laws, regulations and institutional solutions that create an economic everyday life in the country and in a particular market. In times of high unemployment and modest economic growth, effective regulation, effective institutions and public administration, as well as policies that lead to the improvement of the business environment in order to attract investors, can contribute to economic recovery. The simpler processes related to the founding of companies, as well as the possibility for the investor to exit from a nonprofitable business venture, and the flexibility to relocate resources for commercial purposes, allow to reduce activity in areas with a decline in demand and start with new, more promising jobs (provided that reforming the costs of establishment and business become lower or remain the same). Stability in key macroeconomic factors is and legislation relevant to entrepreneurship who is encourages the arrival of investors and capital.

\section{COMPETITIVENESS OF ECONOMY OF BOSNIA AND HERZEGOVINA AND REGION}

On the track in terms of competitiveness of the economy and the private sector, Bosnia and Herzegovina is certainly also indexed with a focus on entrepreneurial activities. The three most heterogeneous global indexes that include Bosnia and Herzegovina are: the Global Competitiveness Index (GCI or Global Competitiveness Report) of the World Economic Forum, the Index of Economic Freedom (IEF) Heritage Foundation, and the
Report on the Doing Business of the World Bank Group. These reports look at the situation in Bosnia and Herzegovina in the sector of competitiveness, business and entrepreneurship in the last four years from the perspective of three global indices, comparing it with the situation in the region.

As an indicator of political stability and stability of the conditions of business, BERI index, ie PRI index and ORI index, can best serve us. It is important to emphasize that potential investors discourage irresponsible policy making, which produces incalculable damage to developing country, its economy and its development. The absence of political stability and the stability of the conditions of business affects the economy to be completely left to the unfavorable global movements of the economy, which has farreaching consequences in the economic development.

Competitiveness is defined as a set of institutions, policies and factors that determine the level of productivity of a country. The level of productivity is the level of progress an economy can achieve. The level of productivity also determines the rates of return on investments that are the fundamental drivers of economic development. A more competitive economy is the one that will grow faster and develop in the future.

Based on the results of a global competitiveness index that provides impartial information that enables leaders in the public and private sectors to better understand the drivers of growth. An overview of the competitiveness of almost 140 economies is presented, giving a comprehensive assessment. It contains a detailed profile of each economy and table with global ranking data with a lot of indicators. 
Using quantitative methods and survey survey data, the Competitiveness Report ranks countries by combining 114 indicators grouped into 12 pillars of competitiveness ${ }^{4}$. Since 2005, the World Economic Forum (WEF) has based its competitiveness analysis on the Global Competitiveness Index (GCI), a comprehensive framework that measures the microeconomic and macroeconomic foundations of national competitiveness consisting of 114 indicators grouped into 12 pillars: Institutions; Infrastructure; Macroeconomic environment; Health and basic education; Higher education and vocational training; Efficiency of the commodity market; Labor Market Efficiency; Development of the financial market; Technological readiness; Market size; Business Sophistication and Innovation.

All pillars are grouped into three groups according to the main stages of development: the phase of the factors (columns 1 to 4 ), the efficiency phase (columns 5-10) and the innovation phase (columns 11 and 12). The Competitiveness Index includes data from internationally recognized institutions, in particular the International Monetary Fund (IMF), the World Bank, the United Nations, various organizations for science and culture, the World Health Organization, UNESCO and the annual World Economic Forum and listed annual reports provide each country with data on qualitative estimates.

The Global Competitiveness Index measures factors that drive long-term growth and progress over the past four decades, helping decision-makers identify challenges they face, but at the same time recognizing the country's benefits in designing economic growth strategies. While the concepts of

4 Federal Program for Development of $\mathrm{BiH}, 2018$ Competitiveness 2017-2018 Bosnia and Herzegovina, Sarajevo

30 competitiveness and the economic environment are constantly changing, the past decade has seen significant shifts in the foundations of political decisions that fuel economic growth.

After a prolonged period of slow growth resulting from the financial crisis, the world economy has finally accelerated progress, which is a very good news, but despite the shifts, decision makers are still concerned when long-term economic development is in question. This is partly due to the fact that the previous expansion is concise and is supported by extremely low interest rates much more than the basic drivers of structural growth. Productivity remained at a low level and failed to return to the level it had in the past decades.

Although all the pillars that are listed to a certain extent significantly affect the country's economy, it is clear that they differ differently on different countries. In accordance with well-known economic theories about development phases, the Competitiveness Index is based on the assumption that all countries are going through three phases of development (Figure 1). 


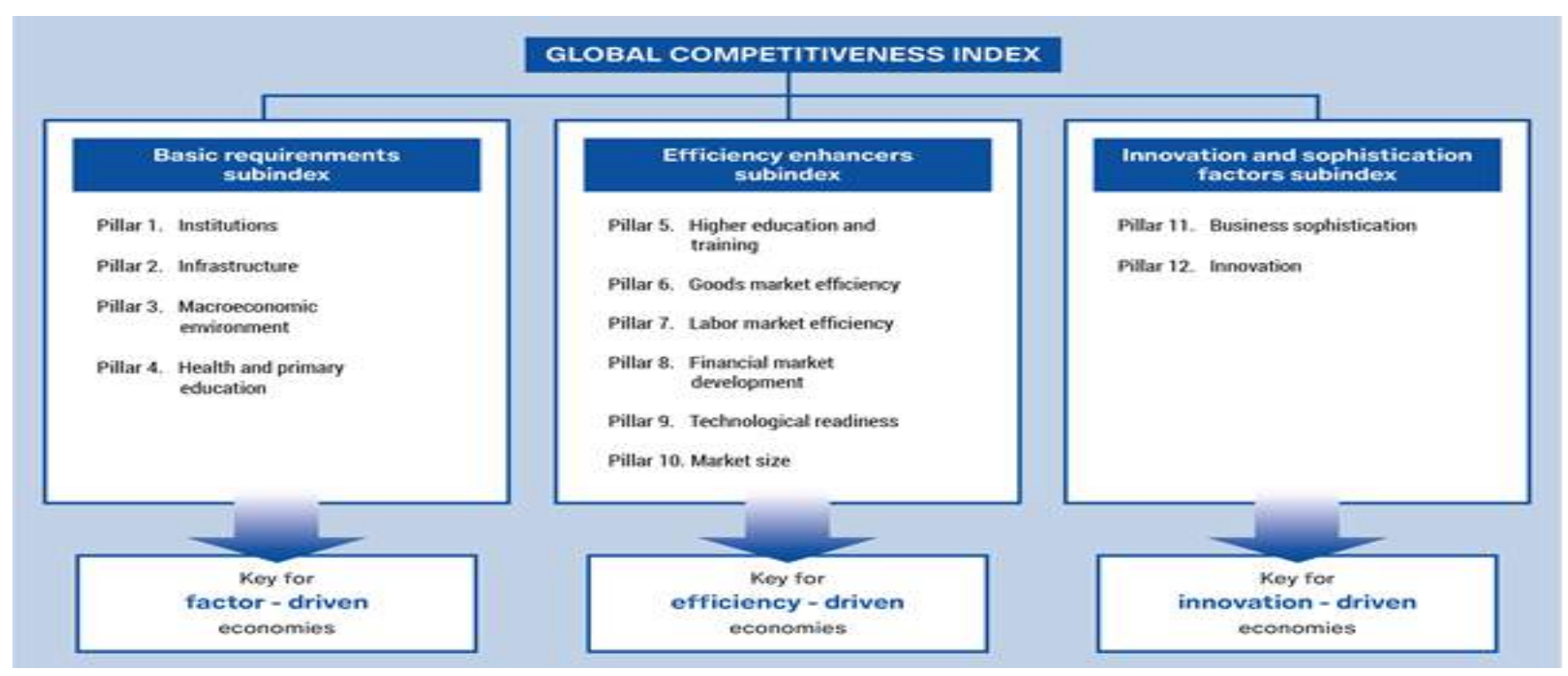

Figure 1: Competitiveness stages

These three groups have different weights in calculating the total index, depending on the degree of development of an economy, relative to its GDP per capita, and the share of raw material exports. Unlike Doing Business, which is focused on the benefits of the business environment and regulation related to the business of small and medium-sized enterprises, GCI takes a broader cross-section of the economy including indicators such as infrastructure, macroeconomic stability, quality of health care and business sophistication.

The GCI also classifies countries in three general levels of development: economies based on factors (whose export structure in the $70 \%$ share consists of ores, minerals and basic products), economyes in based efficient econo-myes and a based economy on innovation or rapid adoption of innovative technologyes. There are also groups of countries that are in the transition between the first and second, respectively the second and third levels. For years, Bosnia and Herzegovina has been in the group of countries whose efficiency-based economy, along with Serbia, Montenegro, Northern Macedonia, and Albania.
The greatest difficulties (negative impact on competitiveness) in Bosnia and Herzegovina continue to be unproductive administration, high tax rates and inadequate legal regulations, as well as political instability and corruption, so it is necessary to compare Bosnia and Herzegovina with the countries of the region according to the Index of Economic Freedom (IEF), which is the Heritage Foundation Index based on 12 quantitative and qualitative factors grouped into 4 broad areas of economic freedom ( Table 1.).

Table 1.: Index of Economic Freedom - IEF

\begin{tabular}{|c|l|l|l|l|}
\hline Area & $\begin{array}{l}\text { The rule of } \\
\text { law }\end{array}$ & $\begin{array}{l}\text { Size of } \\
\text { administra } \\
\text { tion }\end{array}$ & $\begin{array}{l}\text { Regulatory } \\
\text { Efficiency }\end{array}$ & $\begin{array}{l}\text { Market } \\
\text { openness }\end{array}$ \\
\hline \multirow{5}{*}{ Factors } & $\begin{array}{l}\text { Property } \\
\text { rights }\end{array}$ & $\begin{array}{l}\text { Tax } \\
\text { burden }\end{array}$ & $\begin{array}{l}\text { Freedom of } \\
\text { business }\end{array}$ & Free trade \\
\cline { 2 - 5 } & institutions & $\begin{array}{l}\text { Public } \\
\text { spending }\end{array}$ & $\begin{array}{l}\text { Freedom to } \\
\text { work }\end{array}$ & $\begin{array}{l}\text { Free } \\
\text { investme- } \\
\text { nts }\end{array}$ \\
\cline { 2 - 5 } & $\begin{array}{l}\text { Efficiency } \\
\text { of the } \\
\text { judiciary }\end{array}$ & $\begin{array}{l}\text { Fiscal } \\
\text { health }\end{array}$ & $\begin{array}{l}\text { Monetary } \\
\text { freedom }\end{array}$ & $\begin{array}{l}\text { Financial } \\
\text { freedom }\end{array}$ \\
\hline
\end{tabular}

For each country that is observed, the results of these 12 factors (on a scale of 0 to 100) are added together, and their average (where 12 factors are of the same ratio) is taken as the final result of economic freedom for that country. 
The Doing Business Report is the annual report of the World Bank Group that provides objective measurements of business regulations and its implementation for 190 economies and specific cities at regional and supranational levels. The focus of this index is on domestic small and medium-sized enterprises and the perception of regulations that accompany them in the life cycle, and the aim of the index is to provide objectivity in understanding and improving the business environment in all countries. The index is quite specialized and its methodology has been improving over the years in terms of number and depth of indicators. Indicators are grouped into ten thematic groups: starting a business, building permits, introducing electricity, registering ownership, obtaining loans, protecting minority investors, paying taxes, cross-border trade, executing contracts and regulating insolvency.

\section{RESULTS OF THE RESEARCH ON ECONOMY COMPETITIVENESS IN BOSNIA AND HERZEGOVINA AND REGION IN THE PERIOD 2014 - 2018 YEAR.}

\section{Calculation of Global Competitiveness Index 4.0 (GCI 4.0)}

Of the 98 indicators that comprise the GCI 4.0 methodology, 44 are the sources from the WEF Forum survey, and 54 are based on the statistics of reliable external sources. The indicators were selected on the basis of four principles. First, the indicators must adequately cover the concept presented at the top. Secondly, external statistics must be collected from reliable organizations that collect data in accordance with high quality standards. Thirdly, it is expected that the data will be periodically updated in the future. Fourthly, the data must have extensive geographical coverage and be available in at least $75 \%$ of countries covered by the GCI index. Pillars and the index results are expressed on a scale of 0 to 100 and thei are interpreting as "Results of progression", indicating how close the country is to the ideal condition. The overall score of the index is a simple average of 12 pillars, so the weight of each pillar is $8.3 \%(1 / 12)$.

The following table 2. shows the results of competitiveness research based on the Global Competitiveness Index (GCI), a comprehensive framework that measures the microeconomic and macroeconomic foundations of national competitiveness for the countries of the region over the last five years.

Table 2.: Ranking of countries in the region according to GCI in the last five years

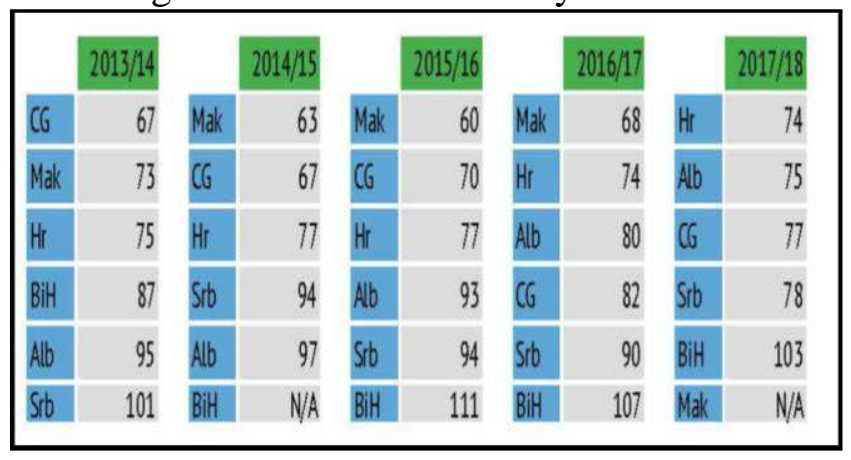

Analyzing the data from Table 2. we conclude that Bosnia and Herzegovina had a much better position according to GCI 2013/2014 than today. However, the situation has improved over the last couple of years, so Bosnia and Herzegovina has advanced from 111th place (from 140 countries) to 103 in the latest report (out of 137 countries). Due to the inability to access data, Bosnia and Herzegovina was not included in GCI 2014/2015. Bosnia and Herzegovina is currently the worst ranked relative to the countries of the region, while Croatia is ranked the best. Over the last three years, Bosnia and Herzegovina has taken the worst position in the region. 
If we look for a number of years, Albania and Serbia have made the most progress, while Montenegro has fallen by as much as 10 positions.

In the following table 3., the results of the survey on the ranking of Bosnia and Herzegovina in the last five years according to the 12 pillars of competitiveness of GCI are presented.

Table 3.: Ranking of $\mathrm{BiH}$ in the last five years according to the 12 pillars of GCI competiti-veness

\begin{tabular}{|c|c|c|c|c|c|c|}
\hline $\begin{array}{l}\text { Bosnia and } \\
\text { Herzegovina }\end{array}$ & $\begin{array}{c}2012 \\
/ 13\end{array}$ & $\begin{array}{c}2013 \\
/ 14\end{array}$ & $\begin{array}{c}2014 \\
/ 15\end{array}$ & $\begin{array}{c}2015 \\
/ 16\end{array}$ & $\begin{array}{c}2016 \\
/ 17\end{array}$ & $\begin{array}{c}2017 \\
/ 18\end{array}$ \\
\hline $\begin{array}{l}\text { 1. Public } \\
\text { administration }\end{array}$ & 70 & 71 & N/A & 127 & 126 & 126 \\
\hline 2. Infrastructure & 82 & 83 & N/A & 103 & 105 & 100 \\
\hline $\begin{array}{l}\text { 3.Macroeconomic } \\
\text { environment }\end{array}$ & 104 & 104 & N/A & 98 & 76 & 64 \\
\hline $\begin{array}{l}\text { 4. Health and } \\
\text { basic education }\end{array}$ & 105 & 104 & N/A & 98 & 76 & 64 \\
\hline $\begin{array}{l}\text { Total: Basic } \\
\text { conditions }\end{array}$ & 81 & 81 & N/A & 95 & 94 & 91 \\
\hline 5. High education & 63 & 63 & N/A & 97 & 92 & 91 \\
\hline $\begin{array}{l}\text { 6. Efficiency of } \\
\text { the commodity } \\
\text { market }\end{array}$ & 103 & 104 & N/A & 129 & 129 & 126 \\
\hline $\begin{array}{l}\text { 7. Flexibility of } \\
\text { the labor market }\end{array}$ & 86 & 88 & N/A & 131 & 125 & 123 \\
\hline $\begin{array}{l}\text { 8. Development of } \\
\text { the financial } \\
\text { market }\end{array}$ & 112 & 113 & N/A & 113 & 101 & 104 \\
\hline $\begin{array}{l}\text { 9. Technological } \\
\text { readiness }\end{array}$ & 72 & 73 & N/A & 79 & 76 & 69 \\
\hline 10. Market size & 96 & 98 & N/A & 97 & 98 & 97 \\
\hline Total: Efficiency & 87 & 89 & N/A & 112 & 106 & 100 \\
\hline $\begin{array}{l}\text { 11. Business } \\
\text { sophistication }\end{array}$ & 110 & 110 & N/A & 125 & 115 & 115 \\
\hline 12. Innovations & 62 & 63 & N/A & 115 & 125 & 123 \\
\hline $\begin{array}{l}\text { Total: Innovation } \\
\text { and sophistication }\end{array}$ & 88 & 89 & N/A & 120 & 122 & 119 \\
\hline IN TOTAL: & $\begin{array}{r}88 / \\
144 \\
\end{array}$ & $\begin{array}{r}87 / \\
148 \\
\end{array}$ & N/A & $\begin{array}{r}111 / \\
140 \\
\end{array}$ & $\begin{array}{r}\mathbf{1 0 7 /} \\
138 \\
\end{array}$ & $\begin{array}{r}\mathbf{1 0 3 /} \\
137 \\
\end{array}$ \\
\hline
\end{tabular}

The results of the survey show that from 2013/2014 to 2017/2018, Bosnia and Herzegovina has significantly declined in ranking in all three areas of the Indian economy, mostly in the innovation and sophistication of business, where it has fallen from 89th place (from 148 countries) to 119 place (of 137 countries). On the other hand, in the last three years, Bosnia and Herzegovina has made the most progress in this area in the field of Efficiency thanks to the progress in higher education, the flexibility of the labor market, the development of the financial market and technological readiness. If we look at the total ranking of $2017 / 18$. In terms of three areas, we see that Bosnia and Herzegovina it best placed under the basic conditions (91), and it is still the worst with the innovation and sophistication of business (119) of 137 countries.

Figure 2. shows the score (1-7) of the global competitiveness index for the period 2012/13 to 2017/18.

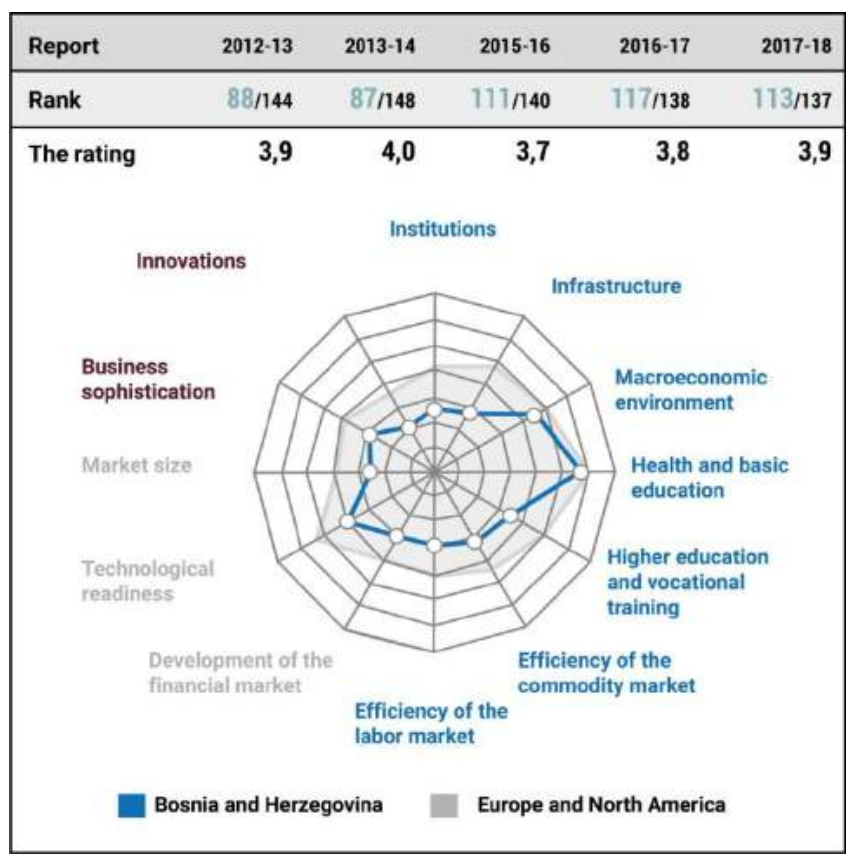

Figure 2.: Evaluation of the (1-7) competitive-ness index for Bosnia and Herzegovina, Europe and North America

Source: IMF; World Economic Outlook Database May 2019.

In order to be able to accurately analyze the data and compare them with the previous results, it should be noted that the analysis of rank, on your own the observed self does not speak much about the progress or the country's title. The analysis should also take into account the results of the assessments so that it can clearly be seen in which area and for how long the country has made progress or reversal. If we look at only one of these components, we can come to the wrong conclusion, for example, that the country has "progressed when it comes to grades", which in reality did not lead to a change in rank or the country was actually ranked even lower than the previous report. 
From the report for 2018, we can see that the Global Competitiveness Index of $\mathrm{BiH}$ records the best ranking in the pillar of business dynamics, in the component of the legal framework of the bankruptcy procedure, which places this component with a rating of 93.7 in the first place in ranking together with 5 other countries and the best ranking in the pillar of infrastructure, in the component of the electrification rate, ie, access to hou sehold electricity, which places this component with a maximum score of 100 in the first place in ranking along with 66 other countries globally. Below, in Figure 3, we give a detailed overview of the rank changes and the score of the competitiveness index in all pillars in relation to the new calculation of the global competi-tiveness index 4.0 methodology. compared to the previous year.

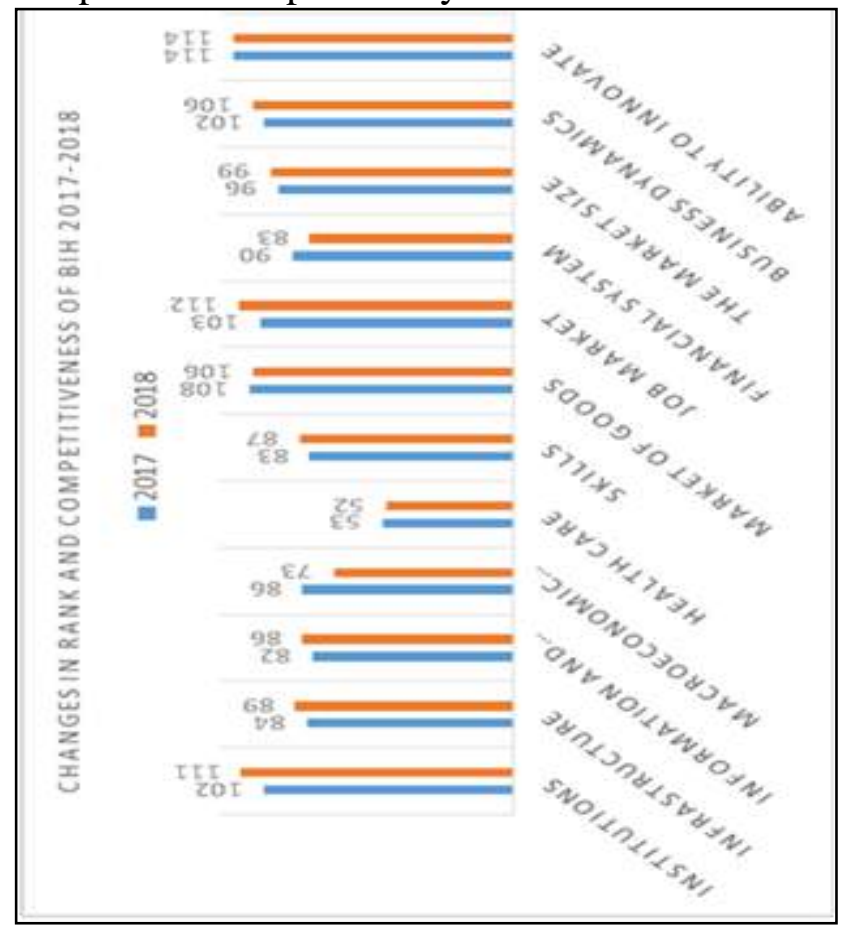

Figure 3.: Changes in rank and competitiveness of $\mathrm{BiH}$ 2017-2018

Source: The Global Competitivness Report 2018, processing of the author

Compared to the previous year, the largest positive change in the ranking is recorded by the pillars of the macroeconomic environment (13), the financial system (7), the commodity market (2) and the pillar of health (1).

The largest negative change in rank was recorded by the pillars of institutions (-9), infrastructure (-5), skills (-4), business dynamics (-4), adoption of information and communication technologies (-4) and market size $(-3)$ the innovation pillar remained unchanged compared to the previous year.

When it comes to estimates of the $\mathrm{BiH}$ competitiveness index, the situation in the order is somewhat different (Figure 4.).

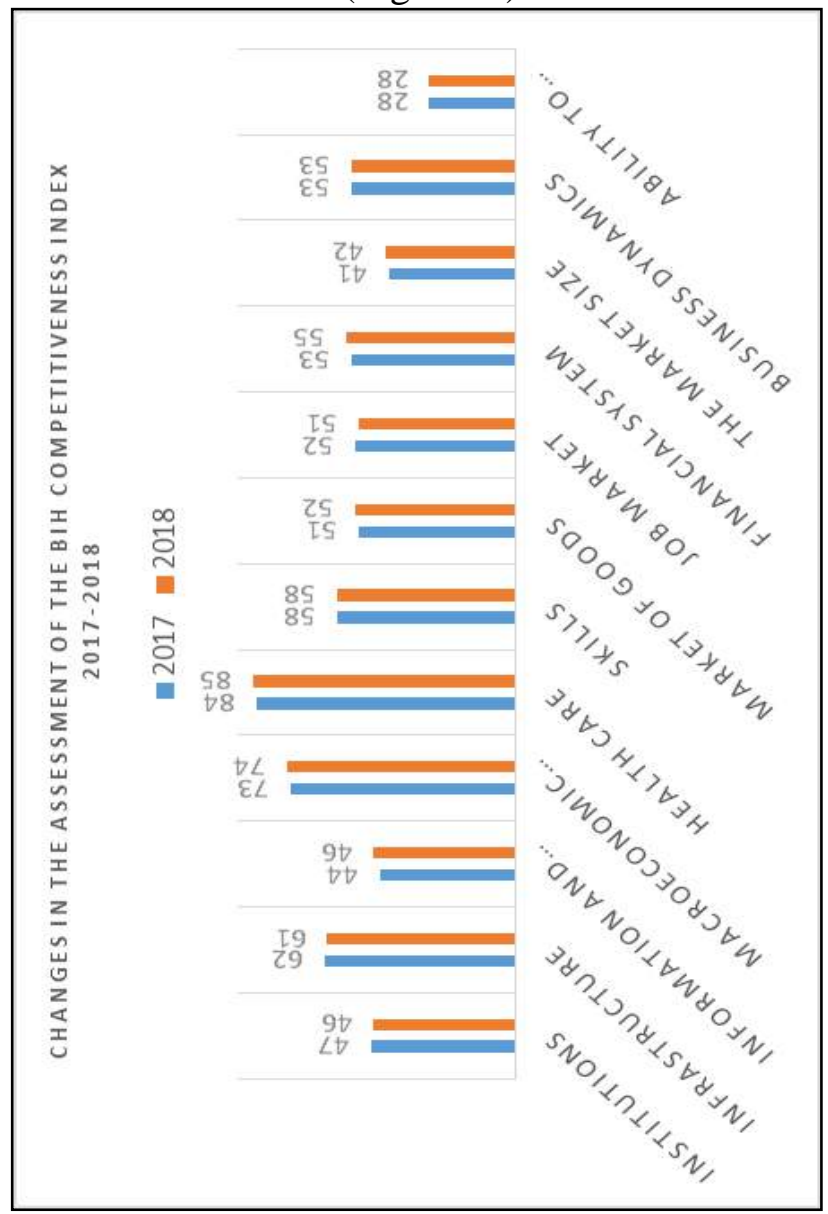

Figure 4.:Changes in the assessment of the $\mathrm{BiH}$ Competitiveness Index 2017-2018

Source: The Global Competitivness Report 2018, processing of the author

Compared to the previous year, the highest positive change in the rating was recorded by the pillars of adoption of information and communication technologies (2.3), the financial system (2.1), macroeconomic stability (1.6), healthcare (0.8), market size (5), product markets (0.4) and business dynamics (0.1).

Although most of the pillars registered an improvement in the rating compared to the previous year, the largest negative change in the rating was recorded by the pillars of institutions (-1.1), infrastructure (-1.0), skills $(-0.8)$ and labor market (-1.0). 
Table 4.: Rank and Ratings of $\mathrm{BiH}$ and the Environment Regions Towards the Pillars of Competitiveness 2018

\begin{tabular}{|c|c|c|c|c|c|}
\hline & Bosnia and Herzegovina & & & & place $91 / 140$ \\
\hline & Index components & Value & Rating & Rank/140 & Best rating \\
\hline & First pillari Institutions $0-100$ (best) & & 45,6 & 101 & New Zeland \\
\hline 1.01 & Organized crime 1.7 & 42 & $\$ 3,1$ & 103 & Finland \\
\hline 1.02 & Murder rate $/ 100,000$ inhabitants & 13 & 97,4 & 42 & Multiple (9) \\
\hline 1,03 & Frequency of terrorism o (very high) - 100 (without terrorism) & 99,9 & 99,9 & 64 & Mustiple (24) \\
\hline 1,04 & Petiability of the police service 1-7 & 3.5 & 413 & 109 & Finland \\
\hline 1,05 & Social capital 0-100 & n'a & $\$ 3,0$ & $n / 2$ & Australia \\
\hline 1.06 & Budget transparency 0-100 & 50 & 50 & $n$ & Multiple (2) \\
\hline 1.07 & Judicial independence $1-7$ & 2.4 & 23,5 & 124 & Fieland \\
\hline 1.08 & The efficiency of the legal tramework in the required regulations & 1,8 & 13,8 & 137 & Finland \\
\hline 1,09 & Medis freedom 0-100 (worst) & 27.4 & 72.6 & so & Norway \\
\hline 1,10 & The buiden of state regulations 1-7 & 22 & 19,8 & 135 & Singapore \\
\hline 1,11 & Efficiency of the Legal Framework in Dispute Alesolution t-7 & 22 & 19,6 & 134 & Singapcere \\
\hline 1,12 & E-participation index 0-1 (best) & 0,4 & 43,3 & 109 & Multiple (3) \\
\hline 1.13 & Gowernment's focus on the future 1.7 & 2.1 & 18,7 & 137 & Singapoee \\
\hline 1,14 & Frequency of corruption 0-160 & 38 & 38 & $n$ & New Zeland \\
\hline 1.15 & Property Rights $1-7$ & 33 & 37,9 & 13 & Finland \\
\hline 1,16 & Inselectual Property Profection 1-7 & 2.9 & 32,3 & 135 & Finland \\
\hline 1,17 & Land Administration Quality 0.30 & 12,5 & 41,7 & 89 & Singapece \\
\hline 1,18 & FTe strength of the audit and reporting standards 1-7 & 3,4 & 40,4 & 129 & Finland \\
\hline 1.19 & Conflict of interest control o-10 & 47 & 47 & 106 & Multiple (2) \\
\hline \multirow[t]{2}{*}{1,20} & Donation managenent 0-10 & 7 & ro & 24 & Kazakhstan \\
\hline & Second pillan Infrastructure 0-100 (best) & & 60,7 & 69 & Sisgapere \\
\hline 2,01 & Pload Link Index $0-100$ & 49,2 & 49,2 & 93 & United States \\
\hline 2,02 & Plosd qualty o-7 & 28 & 30,2 & 117 & Singapore \\
\hline 2.03 & Railway density $\mathrm{km}$ of rosd $/ \mathrm{km} 2$ & 19,9 & 49,7 & 39 & Multiple (20) \\
\hline 2,04 & Efficiency of rali services i-7 & 2,1 & 18,6 & 113 & Switzetland \\
\hline 2,05 & Aerodrome rating association & 2944,1 & 30,9 & 98 & Multiple (8) \\
\hline 206 & Ait Tramk Servikes 1-7 & 3.3 & 37.7 & 122 & Sinsapcee \\
\hline 2.07 & Liner Ship Link Index (LSCI) 0-15] & na $/ \mathbf{a}$ & $\mathbf{n} / \mathbf{a}$ & $\mathrm{n} / \mathrm{a}$ & Mustiple (4) \\
\hline 2,08 & Port services efficiency 1-7 & 20 & 16.2 & 134 & Singapoee \\
\hline 2,09 & Electrification ratefs inh. & 100 & 100 & 1 & Multiple (66) \\
\hline 2,10 & F Electricity transmission and loss of distributien $\%$ & 10,3 & 93,4 & 66 & Multiple (9) \\
\hline 2,11 & Exposure to unstable drinking water\% of inhabitants. & 7.8 & 94,1 & 49 & Mustiple (23) \\
\hline \multirow[t]{2}{*}{2.12} & Fueliability of water suppty I-7 & 42 & 54,1 & 96 & Switzerland \\
\hline & $\begin{array}{l}\text { Third pillar: Adoption of information and communication technologies } \\
\text { o-100 (best) }\end{array}$ & & 45,8 & ss & Kotea, Alep. \\
\hline 3.01 & Subscription to mobile phenes / 100 inhubitants. & 98,1 & 81,7 & 103 & Multiole (69) \\
\hline 3,02 & Subscription to mobile broudband networks / 100 inhabitants. & 43,4 & & 104 & Uhited Arab Emirates \\
\hline 3,03 & Foxed Broadband Internet Subscription / 100 inhabitants. & 18,9 & 37,8 & so & Sinitzerland \\
\hline 3,04 & Subscription to optical internet / 100 inhabitants. & 0,0 & & 96 & Korea Hep. \\
\hline \multirow[t]{2}{*}{2.05} & Internet users\% of population & 60,3 & 60,3 & 66 & Iceland \\
\hline & Fourth pillar: Maccoeconomic enviconement 0-100 (best & & 74,4 & 73 & Multiple (31) \\
\hline 4.01 & 4.01 inflation\% of annual change & 0.1 & 98,8 & $\infty 2$ & Multiple (74) \\
\hline \multirow[t]{2}{*}{402} & Debt dynamics o-100 & 50 & 50 & 64 & Mustiple (36) \\
\hline & Finth pillar: Hesith 0-100 (best) & & 85,3 & 52 & Mutiple (4) \\
\hline \multirow[t]{2}{*}{5.01} & Hit expected life span years & 67,3 & 85,3 & 51 & Multiple (4) \\
\hline & Sixth pillar: Skills $0-100$ & & 57.5 & 87 & Fileland \\
\hline 6.01 & Mean value of education duration years & 90 & 60,0 & 74 & Finland \\
\hline 6.02 & Staff training i-7 & 3.0 & 33,8 & 133 & Switzerland \\
\hline 6.03 & Cuality of prodessional development i-7 & 3.1 & 35,7 & 120 & Sinitzerland \\
\hline 6,04 & Skills graduates $1-7$ & 32 & 36,0 & 130 & Switzerland \\
\hline 6.05 & Digital skills among the population 1.7 & 3.8 & 47,1 & 8 & Swedea \\
\hline 6.06 & The esse of finding quality workers & 3.3 & 38,1 & 130 & Uniled States \\
\hline 6.07 & Expected duration of education of the year & 142 & 78.9 & 68 & Multiple (9) \\
\hline 6,08 & Critical Thinking in Teaching i-7 & 25 & 24,5 & 130 & United States \\
\hline 6.09 & Fatio of pupls and teschers in elementary education share & 17.3 & 81,8 & 58 & Multiple (6) \\
\hline
\end{tabular}


When it comes to individual components that have the greatest influence on the improvement of rank in the pillar of the macroeconomic environment, the annual percentage change in the consumer price index is highlighted inflation, which within the pillar recorded a positive change in the rating by 3.2 , which influenced the improvement of rankings by 22 places compared to the previous year. Countries with an inflation rate ranging from $0.5 \%$ to $4 \%$ recorded the best results. Beyond this range, the results are reduced linearly so that the difference between the optimum and the actual value increases. Further improvement within this pillar requires an unchanged state of the debt dynamics component which which, a score of 50 , holds keeps it rank of 64 places.

In the financial system pillar, the components that had the greatest influence on the improvement of the ranking were capitalization of the market whose positive change of grade of 8.9 influenced the improvement of the rankings by 12 places, while the second best change in the assessment of 4.8 components of bank security influenced the improvement of the ranks of this pillar for 8 places. What still demands a special improvement within this pillar are the components of capital availability for a star-up company whose downgrade by 3.4 points led to a deterioration of the rankings by 14 places, and a component of domestic loans to the private sector as\% of GDP, a 0.6-point reduction led to a 10-point deterioration.

In the product market pillar, the components that only affected the improvement of the ranking were the importance of non-tariff barriers, which increased the rating by 9.5 , influencing the change of rank by 49 places, as well as the component of competitiveness of services whose increase in rating by 3.9 influenced the increase in rank for 5 places. Further improvements within this pillar require distortion effects of tax and subsidies to competition whose reduction of a score of
0.9 has affected the deterioration of the rank by 10 places, and the extent of market dominance characterized by corporate governance and whose 0.7-point decline affected the deterioration rank for 8 places.

When it comes to individual components that have most affected the worsening of rankings in the pillar of institutions, the highest point is the result of the E-participation index, which records a negative change of rating by 7.6, which affects the worsening of the rankings by 23 places compared to the previous year. This index evaluates online government services in facilitating citizen information (einformation), stakeholder interaction (econsultation), and decision making (e-decision making).

The component of the efficiency of the legal framework in dispute resolution also recorded a negative change in the score of 7.3 , which affected the 12-point ranking, and the burden of state regulations whose reduction of grade 5.0 affected the ranking by 10 places. What can be pointed out as progress in this pillar is a positive change in the ratings of some components, of which the greatest progress has been recorded in the component that assesses the frequency and severity of terrorist attacks in a five-year period and whose change in the score of 0.1 has affected the ranking by 12 places .

The Organized Crime Component recorded an increase in the rating of 4.3 , which affected the increase in rankings by 7 seats. Further improvements within this pillar require components that have remained unchanged compared to the previous year, and this particularly applies to budget transparency, the quality of land administration, the regulation of conflict of interest and shareholder management. 
In the pillar of the infrastructure, the components that had the greatest influence on the worsening of the ranking were reliability of water supply (lack, breaks and flows), whose change of rating for 7.8 influenced the worsening of the rank by 28 places, the components of the efficiency of rail services whose change of rating was 0.9 influenced the worsening of the rankings by 11 places and the component of road quality whose change of rating by 3.5 influenced the deterioration of the rankings by 9 places compared to the previous year.

The pillars of the component components that have the greatest impact on the worsening of the rank are the skills of graduates, which include graduates who have the skills to work in companies and whose change of grade for 3.4 influenced the deterioration of rank for 12 places, the quality of professional development whose change of grade for 1.7 impacted the deterioration of the rankings for 9 places and critical thinking in education, whose change in grade for 3.2 influenced the deterioration of the rankings by 9 places compared to the previous year. What can be highlighted as the only progress in this pillar is a positive change in the assessment of digital skills among the population whose change of rating by 0.2 influenced the improvement of rank for one place.

In the pillar of business dynamics, the components that mostly affected the worsening of the ranking were the willingness to delegate authority whose negative change of rating for 5.4 affected the deterioration of the rankings by 13 places and the component of the growth of innovative companies, although the positive change in the rating for 2.3 nevertheless affected worsening rank for 2 places. Within this pillar, progress has been recorded in the start-up components of the company whose increase in the rating by 2.9 influenced the improvement of rankings by 13 positions, the components of the attitude towards entrepreneurial risk whose increase in the rating affected the improvement of the rankings by 2 places and the rates of return (ease of business methodology) whose change of grade for 2.4 influenced the improvement of rankings for 2 places.

Overall, compared to all components, the worst change in the score was recorded by the component of internal labor mobility with a negative change of grade of 11.4, which affected the deterioration of the rankings by 69 places compared to the previous year.

The structure of the factors that most disturb business in $\mathrm{BiH}$ and thus most affect the low level of competitiveness of the $\mathrm{BiH}$ economy (measured on a scale of $0 \%-100 \%$ ) are: inefficiency of the state administration (14.2\%), corruption (11.5\%), tax instability (10.5\%), political instability (9.7\%), government instability (9.3\%), access to finance $(8.8 \%)$, complexity of tax regulations $(6.9 \%)$, restrictive labor regulations $(6.5 \%)$, crime and theft (5.6\%), labor ethics (5.2\%), inadequate workforce training $(3.7 \%)$, inadequately secured infrastructure $(2.6 \%)$, insufficient innovation capacity $(2.5 \%)^{5}$.

\section{BOSNIA AND HERZEGOVINA AND THE COUNTRY OF ENVIRONMENT IN COMPETITIVENESS 2018}

Rank and Rating of $\mathrm{BiH}$ and countries of the competitiveness index environment in 2018 according to GCI 4.02018 are shown in the following table 4 . and in graphic torepresentation of painting 5 .

\footnotetext{
5 Šušić M., 2019 Significance and influence of foreign investmentson the economic developme-nt of Bosnia and Herzegovina(Doctoral dissertation), Banja Luka: University of Business Studies
} 
Table 4.: Rank and Rating of $\mathrm{BiH}$ and countries of the competitiveness index environment in 2018 according to GCI 4.0 2018

\begin{tabular}{|l|l|l|l|}
\hline $\begin{array}{l}\text { Ordinary } \\
\text { number }\end{array}$ & Economy & $\begin{array}{l}\text { Ranking of } \\
\text { countries in } \\
\text { the } \\
\text { environment } \\
\text { according to } \\
\text { GCI 4.0 2018 }\end{array}$ & $\begin{array}{l}\text { Rating of } \\
\text { countries in } \\
\text { the } \\
\text { environment } \\
\text { according to } \\
\text { GCI 4.0 } \\
2018\end{array}$ \\
\hline 1. & Slovenia & 35 & 69,6 \\
\hline 2. & Serbia & 65 & 60,9 \\
\hline 3. & Croatia & 68 & 60,1 \\
\hline 4. & Montenegro & 71 & 59,6 \\
\hline 5. & Albania & 76 & 58,1 \\
\hline 6. & $\begin{array}{l}\text { Northern } \\
\text { Makedovia }\end{array}$ & 84 & 56,6 \\
\hline 7. & $\begin{array}{l}\text { Bosnia and } \\
\text { Herzegovina }\end{array}$ & 91 & 54,2 \\
\hline
\end{tabular}

Source: World economic forum, Global competitivenes report 2018, processing of the author

According to the new methodology of the index, the best results were achieved this year by Slovenia, which remained on the same 35th place. It can be said that the best results were achieved by Serbia, which ranks in the 65th position out of 70th place in comparison with the previous year, and Albania, which ranks 76 th out of 80th place in comparison with the previous year, while Croatia, although ranked well in relation to countries environments with slightly lower rankings than last year, from 66th place positioned at 68th place. Montenegro has made progress, and ranked 77 th out of 77 th place, while Macedonia is again ranked again this year and occupies 84th place. Of the 7 countries in the region, Bosnia and Herzegovina has fallen for one place and is still ranked in the last, 91 st place.

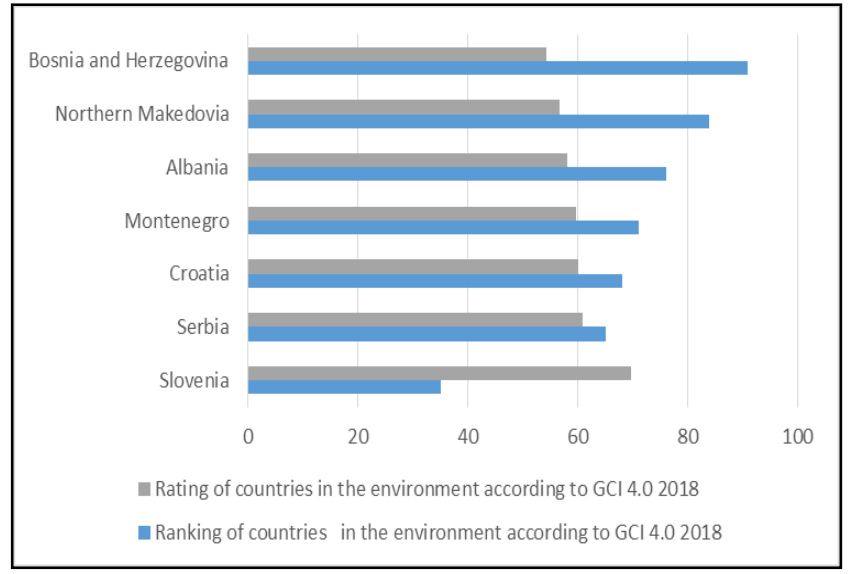

Figure 5.: Rank and Rating of $\mathrm{BiH}$ and the Regions according to the index competitiveness in 2018 according to GCI 4.0 2018

Source: The Global Competitivness Report 2018, processing of the author

The causes of poor competitiveness in attracting FDI are the reports of world organizations $\mathrm{BiH}$ ranked among the latter as attractive for investment in the region. Thus, according to the Global Competitiveness Report for 2018, BiH ranked 91st out of 140 rated countries. Out of the 12 areas in which efficiency is assessed, $\mathrm{BiH}$ has the lowest rating in market efficiency, labor market efficiency and state institutions, while it is best rated in the area of macroeconomic stability.

The World Bank report "Doing Business 2019" provides a similar assessment for $\mathrm{BiH}$. Comparing the quality of the business environment of $\mathrm{BiH}$, it still lags behind other countries in the region. In the report, $\mathrm{BH}$ is ranked 89th, while Macedonia is the best ranked 10th, followed by Serbia (48th), Croatia (58th) and Albania (63rd). As a positive reform in $\mathrm{BiH}$ that should contribute to better competitiveness in 2018 , the adoption of the labor market law is stated. ${ }^{6}$ 


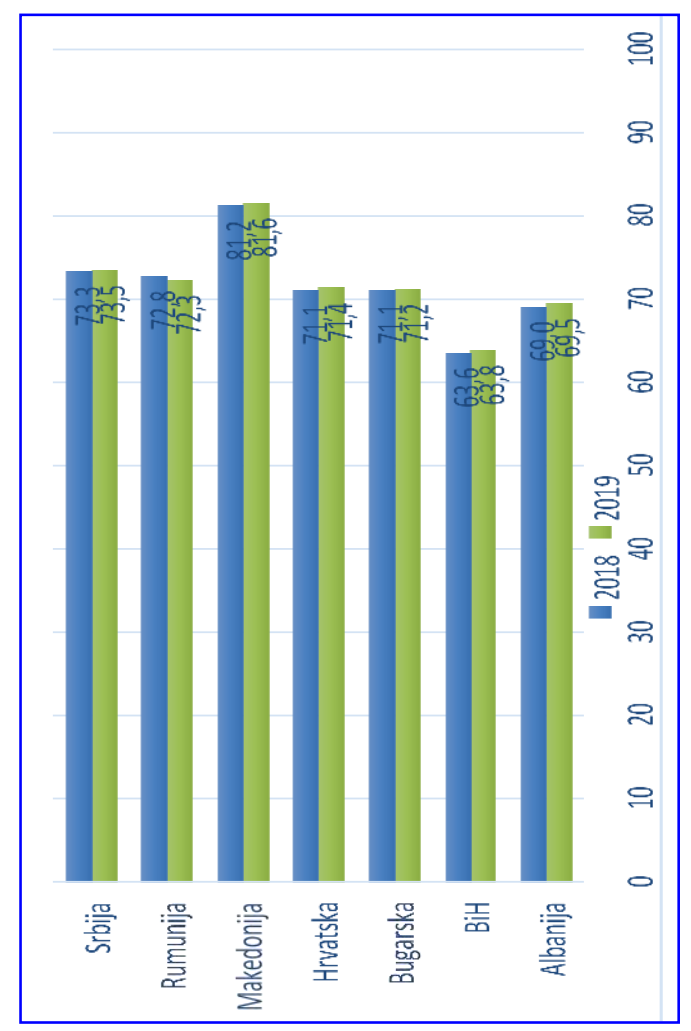

Figute 6.: Doing Business Index for 2018 and 2019

Source: World Bank, Doing Business Database

Of the ten indicators included in the Doing Business Report, $\mathrm{BiH}$ is best placed in crossborder trade (37th place) and in the field of resolving insolvency (37th place) and obtaining loans (60th place). Of all indicators, the lowest was ranked in the field of business start-up (183th place) and in the field of obtaining building permits (167th place).

\section{CONCLUSION}

In the midst of rapid technological change, political polarization and a fragile economic recovery, it is critical that we define, assess and implement new pathways to growth and prosperity. With productivity the most important determinant of long-term growth and income, the new Global Competitiveness Index 4.0 featured in this work sheds light on a newly emerging set of factors critical for productivity in the Fourth Industrial
Revolution (4IR) and provides a tool for assessing them. The key findings below summarize the new tool as well as its results as revealed, regional and country level analysis.

Each country should strive to maximize its ratings in each of the indicators, because the boundary (100) corresponds to the desired target for each indicator and usually represents a political goal. The result shows its current progress in relation to the boundary, as well as the remaining distance. This approach emphasizes competitiveness for all countries.

In essence, the Competitiveness Index offers each economy an equal place for progress by defining its path to growth. While the path depends on the priorities of each economy, the index shows that countries must have a holistic approach to understanding competitiveness rather than focusing only on certain factors. High grades in one column can not compensate for poor grades in another. For example, investing in technology without investing in digital skills will not significantly increase productivity. In order to increase competitiveness, no area should be ignored.

The results of the survey show that from 2013/2014 to 2017/2018, Bosnia and Herzegovina has significantly declined in ranking in all three areas of the Indian economy, mostly in the innovation and sophistication of business, where it has fallen from 89th place (from 148 countries) to 119 place (of 137 countries). On the other hand, in the last three years, Bosnia and Herzegovina has made the most progress in this area in the field of Efficiency thanks to the progress in higher education, the flexibility of the labor market, the development of the financial market and technological readiness. 
If we look at the total ranking of 2017/18. In terms of three areas, we see that Bosnia and Herzegovina is best placed under the basic conditions (91), and it is still the worst with the innovation and sophistication of business (119) of 137 countries.

The results for Bosnia and Herzegovina, compared to the previous year, show that the largest positive change in the rankings is the pillars of the macroeconomic environment (13), the financial system (7), the commodity market (2) and the pillar of health (1).

The largest negative change in rank was recorded by the pillars of institutions (-9), infrastructure (-5), skills (-4), business dynamics (-4), adoption of information and communication technologies (-4) and market size $(-3)$ the innovation pillar remained unchanged compared to the previous year.

And in 2018, Bosnia and Herzegovina is the least competitive country from all countries of the European continent. We can conclude, when the competitiveness of Bosnia and Herzegovina is concerned, that this year's report shows the weaknesses of the country to which decision-makers must pay attention and expedite work to solve them, in order to create conditions in which to pay off investing in the country, and therefore increased opportunities for the growth of standards of all citizens of the country. Bosnia and Herzegovina, without delay, must implement structural reforms in order to achieve a higher level of competitiveness as a prerequisite for economic growth and much desired employment growth.

\section{LITERATURE}

Moran, T.H. Foreign Direct Invetment and Development, Peterson Institute for Internnational Economics, Washington, 2011. str. 30-31.

Stiglitz, J.E. The Economics of Public Sector, McGraw Hill, 2-nd Edition, London, 2003. str. 271.
Blanchard, O. Macroeconomics, Prentice Hall, New York, 2003. str. 526.

Federal Instituta for Development Progra-mming, Bosnia and Herzegovina, Sarajevo; 2018 (http://www.fbihvlada.gov.ba)

Šušić M., 2019 Significance and influence of foreign investmentson the economic developme-nt of Bosnia and Herzegovina, Banja Luka: University of Business Studies

IMF; World Economic Outlook Database May 2019.

World economic forum, Global competitivenes report 2018, processing of the author

https://int.search.tb.ask.com/search/GGmain.jhtml https://flia.org/global-competitiveness-report2018/

www.worldbank.org/content/dam/doingBusiness/media /Annual-Reports/English/DB2019-report_web-versio 